\title{
Transit Camps for Deported Poles in Potulice, Smukała, Tczew and Toruń as a Source of Cheap Labour
}

\author{
Obozy przejściowe dla wysiedlonych Polaków w Potulicach, \\ Smukale, Tczewie i Toruniu jako źródło taniej siły roboczej
}

\section{- Abstrakt •}

Tworzenie przez niemieckie władze okupacyjne obozów przesiedleńczych wiązało się z realizacją planu możliwie szybkiej germanizacji ziem polskich włączonych do Trzeciej Rzeszy. Kierowano do nich polskie rodziny wysiedlone z mieszkań i gospodarstw rolnych, które przejmowali niemieccy osadnicy oraz niemieccy funkcjonariusze aparatu administracyjno-partyjnego. W Okręgu Rzeszy Gdańsk-Prusy Zachodnie najwcześniej, bo w listopadzie 1940 r., utworzono obóz przesiedleńczy w Toruniu, w lutym 1941 r. obóz taki założono w Potulicach koło Nakła i mniej więcej w tym samym czasie zaczął działać obóz przesiedleńczy w Tczewie, a z 1 września 1941 r. jego rolę przejął obóz w Smukale koło Bydgoszczy. Niniejszy artykuł pokazuje, jak wraz z rozwojem sytuacji wojennej ewoluowała rola obozów Centrali Przesiedleńczej, a zwłaszcza jaką rolę odgrywały tego typu obozy w procesie pozyskiwania przez niemieckiego okupanta taniej siły roboczej.

\section{- Abstract •}

Deportee camps or transit camps were established by the German occupation authorities to implement the plan for rapid Germanisation of Polish territories incorporated into the Third Reich. The camps were populated by Polish families ousted from their houses and farms, which in turn were taken over by German settlers and officials of the German administrative and party apparatus. The first such camp for displaced persons was formed in Torun in the Danzig-West Prussia Province in November 1940; in February 1941 a similar camp was set up in Potulice near Nakło, and at about the same time another deportation camp started to operate in Tczew. On September 1, 1941 the role of the latter was taken over by the camp in Smukała near Bydgoszcz. The present paper shows how the role of the Central Emigration Office camps was evolving together with the developing situation on the fronts of the war - the particular focus of this work is the role such camps played as a source of cheap workforce for the German occupant. 
Słowa kluczowe: II wojna światowa; obozy przesiedleńcze (przejściowe, zbiorcze); Okręg Rzeszy Gdańsk-Prusy Zachodnie; Potulice; Smukała; Tczew; Toruń
Keywords: World War II; resettlement camps (transit camps, deportation camps); Reichsgau Danzig-West Prussia; Potulice; Smukała; Tczew; Toruń

Adolf Hitler's Annexation Decree of October 8, 1939 (which entered into force on October 26 of the same year) established, among others, the West Prussia Province (Reichsgau Westpresussen), renamed Danzig-West Prussia Province (Reichsgau Danzig-Westpreussen) on November 2, 1939 (Erlass des Führers vom 8. Oktober 1939, Erlass des Führers vom 2. November 1939) ${ }^{1}$. It covered an area of 26 055,65 square $\mathrm{km}$ and was inhabited by approximately 2.3 million people. It encompassed the Free City of Gdańsk (Danzig), six East Prussia districts [Elbing (now Elbląg) - urban, Elbing - rural, Marienberger (now Kwidzyn), Marienburg (Malbork), Rosenberg (now Susz) and Stuhm (now Sztum) and most of the pre-war Pomeranian voivodship (without the poviats or districts of Inowrocław, Włocławek, Szubin and Nieszawa)] (Pospieszalski, 1946, pp. 9-11; Jastrzębski \& Sziling, 1979, p. 51). The governor and gauleiter of this administrative unit, Albert Forster, clearly laid out his plans for this territory, inter alia in a speech delivered in Bydgoszcz on November 27, 1939: "We are sent by the Führer to this country as trustees of the German cause with a clear goal - to make this territory German again. It will be a glorious task indeed to do our utmost so that soon all Polish aspects, no matter of what nature, will be eliminated. This is particularly true of the ethnic cleansing of this district. Who belongs to the Polish nation must leave this territory"2. Among the wide arsenal of methods and means by which Albert Forster's "ethnic cleansing" was implemented an important place was occupied by displacement of the Polish population and German re-settlement in the area.

At the level of central authorities of the Third Reich, the deportation and resettlement action was coordinated by the Reich's Commissar for the Strengthening of German Nationhood, a post assigned on October 7, 1939 to Reichsführer of the SS and head of the German Police, Heinrich Himmler (Datner, Gumkowski \& Leszczyński, 1960, Doc. no 1, pp. 33-35). In individual administrative units established in the annexed Polish territories, Himmler appointed his plenipotentiaries (Beauftragter des Reichskommissars für die Festigung des deutschen Volkstums)

1 For more information on administrative division of the Polish territories under occupation see: Janowicz (1951); Madajczyk (1970, pp. 64-71).

2 Own translation of original text in German quoted after: Sziling (2006, p. 544). For more information on nazi policy see inter alia in: Grochowina \& Kącka (2014, pp. 173-192). 
- senior SS and police commanders. In the Danzig-West-Prussia Province, this function was performed by SS-Gruppenführer Richard Hildebrandt ${ }^{3}$.

The order for the start of expulsions of Poles from the territories incorporated into the Third Reich and their transfer to the area of the General Government (Generalgouvernement) was issued by the Reich's Commissar for the Strengthening of German Nationhood on October 30, 1939 (Datner, Gumkowski \& Leszczyński, 1960, Doc. no 2, pp. 36-39; Jastrzębski, 1968, pp. 30-33). The entire population which in the opinion of the German authorities was not suitable to undergo Germanization was to be ousted from these lands. In a secret memorandum of November 25, 1939, entitled "Treatment of the population of formerly Polish territories from a racial and political point of view" (Die Frage der Behandlung der Bevölkerung der ehemaligen polnischen Gebiete nach rassenpolitischen Gesichtspunkten), drawn up by Dr. Erhard Wetzel and Dr. Gerhard Hecht of the NSDAP Office of Racial Policy, it was specified that all Poles that settled in the annexed Polish areas after October 1, 1919, Polish intelligentsia, social and political activists, "neutral" Poles not fit to undergo Germanization, Jews and those of mixed Polish-Jewish background (Biuletyn Głównej Komisji Badania Zbrodni Niemieckich w Polsce, vol. IV, pp. 153-160) were to be deported to the territory of Restpolen, "The Remnant of Poland", i.e. the General Government.

In the Reich Province of Danzig-West Prussia, the expulsion action was initially run by the Special Division for the Evacuation of Poles and Jews (SD-Sonderreferat für Evakuierung der Polen und Juden) controlled by the Security Police Inspectorate (Sicherheitspolizei, Sipo) and the Security Service (Sicherheitsdienst, SD) in Gdansk (Danzig), and managed by SS-Hauptsturmführer Franz Abromeit. On November 15, 1939 a separate administrative unit was created to coordinate this action, namely the Central Emigration Office (Umwandererzentralstelle Danzig, $U W Z$ Danzig) with headquarters in Gdynia. The relevant powers of attorney to direct the work of UWZ were extended to the then head of the Secret State Police Office in Gdańsk (Geheime Staatspolizeileitstelle Danzig), SS-Sturmbannführer Hans Wolff. His immediate superior was the Inspector of security police and security service in Gdansk, Helmuth Willich, while the administrative matters of the Central Emigration Office were put in the hands of SS-Hauptsturmführer Franz Abromeit (Jastrzębski, 1967, pp. 10-12; Jastrzębski, 1968, pp. 34, 37, 42-43; Jastrzębski \& Jaszowski, 1968, pp. 20-21; Orski, 1999, pp. 95-96).

${ }^{3}$ More on the topic of expulsions inter alia in: Jastrzębski (1968, pp. 12-29); Madajczyk (1970, pp. 306-323), 
To carry out its work, the Central Emigration Office used what was commonly known as "transit camps' or "resettlement camps" (Übergangslager, Durchgangslager), but also by terms such as: Umsiedlungslager (displaced persons camp), Sammellager (deportation or deportee camp), Internierungslager (internment camp). Discussing the issue of forced labor in such camps set up by the German occupant in Potulice, Smukała, Tczew and Torun requires previous analysis of changes in their organizational structure.

The first transit camp was opened in November 1940 in Torun, located on the premises of the former lard processing and edible oil manufacturing plant "Standard" (established in 1930) at Grudziądzka 124/126 (Graudenzerstrasse 124/126) due to this location, the camp was colloquially termed "Szmalcówka" (from Polish expression smalec, lard). On February 1, 1941, another deportees camp was set up in Potulice near Nakło (Umsiedlungslager Potulitz), in a palace and park complex belonging to the Potulicki family. The resettlement camp in Tczew started operating at about the same time, in the adapted facilities of the abandoned machine factory "Arkona". The camp in Tczew functioned until March 1941; from September 1, 1941 its role was taken over by the camp in Smukała near Bydgoszcz, located on the premises of the former "Karbid Wielkopolski" plant (Obozy hitlerowskie, pp. 398-399, 458-459, 518, 522; Jastrzębski, 1967, p. 13; Jastrzębski, 1968, p. 107; Jastrzębski \& Jaszowski, 1968, pp. 23, 28; Ceran, 2011).

Mid-March 1941, at the request of general governor Hans Frank, deportee transports to the General Government territory were halted due to significant overpopulation of this area and the resulting inability to provide at least a minimum subsistence level for the inflow of displaced persons. This stoppage of the expulsion action was also partially caused by preparations of the Third Reich for aggression on the USSR, which commandeered all means of transport, including rail (Jastrzębski, 1967, p. 20; Jastrzębski, 1968, p. 85; Jastrzębski \& Jaszowski, 1968, p. 23). By March 15, 1941, a total of 11,477 people were displaced from the Danzig-West Prussia Province - all of them were deported to the GG territory as until that time the occupants were unable to ensure conditions allowing them to adopt a selection process among the expelled population (Jastrzębski \& Jaszowski, 1968, p. 23).

After the borders of the General Government closed to resettlement transports, the document decisive for the future of camps managed by the Central Emigration Office in Gdansk was the circular issued by Reichsführer-SS and chief of the German police, Heinrich Himmler on May 28, 1941. It was addressed to all security police officers in the Reich and in the occupied countries, as well as to the central SS and police institutions in Berlin. It contained an instruction to estab- 
lish at least one reeducation labor camp in every province of the Reich, justified in the following way: "In enterprises important from the point of view of wartime economy and national economy, the share of labor performed by foreigners and other forces has increased, which resulted in multiplication of cases of refusals to work, which [...] must be resisted by all means. Persons who refuse to work or otherwise threaten the ethics of work must, to maintain proper order and security, be placed in police custody, and then transferred to reeducation labor camps where they would be taught regular work. Reeducation labor camps are intended solely for those refusing labor or lazy individuals whose behavior is equivalent to the sabotaging of work. Referral [to a reeducation labor camp] is intended to achieve an educational goal, is not considered a punitive measure and can not be thusly officially perceived" (Gräfe, Post \& Schneider, 2009, p. 201). Reeducation labor camps were to be created through the headquarters of the Reich Security Main Office (Reichssicherheitshauptamt, RSHA) and district inspectors of the security police and security service, responsible inter alia for selecting the Gestapo outlets that were to control these camps. Following the above quoted circular issued by H. Himmler on May 28, 1941, the Security Police and Security Service Inspector in Gdansk, SS-Standartenführer Helmuth Willich, wrote to Reinhard Heydrich, head of the Reich Main Security Office. In the letter of July 7, 1941 he suggested the former civilian prisoners of war camp Stutthof and the camp in Potulice managed by the Central Emigration Office as locations to establish a reeducation labor camp - to be controlled by Gestapo headquarters in Gdańsk (Staatspolizeileitstelle Danzig) (Gliński, 1977, pp. 212-214). H. Willich thus justified the need for such a camp to be created in the region controlled by him: "Behavior of Poles in the Reich Province Danzig-West Prussia remains, as all my reports indicate, still recalcitrant, with continuous refusals to work and acts of sabotage plaguing us in particular. Also the Labor Offices inform me of refusals to work being a daily occurrence. From the point of view of the security police, Poles expelled from their homes to make place for the settlement of Germans from Bessarabia are particularly dangerous. According to standards previously in force, displaced persons were first sent to the Central Emigration Office camps and there assessed by the relevant Labor Offices according to the criterion of suitability for work and sent to farms as workers [...]. While the Poles selected to work did, at the command of Umwandererzentralstelle, report to the police stations at their assigned work location, shortly after they tended to abandon their jobs without approval of the Labor Offices and the Police, and took to roving, finding shelter with people just like them in the whole of Danzig-West Prussia Reich Province" (Gliński, 1977, p. 213). In a letter dated August 9, 1941, R. Heydrich informed H. Willich of the 
approval for turning the Stutthof camp into a reeducation labor camp controlled by the Gestapo headquarters in Gdańsk (Gliński, 1977, pp. 217-218). On September 25, 1941, H. Willich appointed the former commander of the Stutthof camp, SS-Sturmbannführer Max Pauly as commandant of the new reeducation work camp Stutthof, and at the same time "in order to unify the camps managed by the Central Emigration Office" gave him "supervision and management powers" over the camps in Potulice, Torun and Smukała (Gliński, 1977, pp. 218-220) After taking on this new function, M. Pauly became directly subordinate to the Security Police and Security Service inspector in Gdańsk (Danzig). Camps previously overseen by the Central Emigration Office retained their names, and M. Pauly supervised them through camp commanders (Lagerführer) he personally appointed. They were officers from the staff of the Stutthof camp: SS-Obersturmführer Richard Reddig in Toruń, in Smukała SS-Obersturmführer Erich Gust (later, probably from November 1941, replaced by SS-Oberscharführer Fritz Weber), and the Potulice camp was headed personally by M. Pauly. In practice, M. Pauly spent most of his time in the Stutthof camp, so he was represented in the Potulice camp by SS-Untersturmführer Paul Ehle as his deputy. In December 1941, Paul Ehle became the official commandant of the camp in Potulice (Order of the commandant of the Stutthof camp, Max Pauly of September 27, 1941; Jastrzębski, 1967, pp. 32-34; Jastrzębski \& Jaszowski, 1968, pp. 33-34; Orski, 1999, pp. 94-95, 97-98; Orski, 2004, pp. 191-192). At the end of 1941, 2,393 people were imprisoned in Potulice, in Torun the count was 2,850 people, and in Smukała 1,428 people were detained (Jastrzębski, 1968, p. 107).

Further changes in the organizational structure of the camps in Potulice, Smukała and Toruń were introduced on January 20, 1942, when the camps were once more taken over by the Central Emigration Office. At that point, new commandants were appointed for all three camps: in Potulice this position was taken up by SS-Hauptsturmführer Waldemar Tennstaedt, in Smukała by SS-Oberscharführer Franz Wink and in Toruń by SS-Obersturmführer Willi Ehlert (Letter from Security and Security Service Inspector in Gdańsk, SS-Oberführer Helmuth Willich, of January 28, 1942). On September 1, 1942 the camps in Smukała and Torun became sub-camps (Unterlager) of the Potulice camp, which was promoted to the role of a central transit camp. SS-Sturmbannführer Riller served as its first commandant (in January 1944 this function was taken over by SS-Sturmbannführer Hermann Ling, who in turn was replaced in May 1944 by SS-Obersturmbannführer Schultz) (Jastrzębski, 1967, pp. 36-38; Jastrzębski \& Jaszowski, 1968, pp. 36-38). In February 1943 the camp in Smukała was liquidated and its prisoners were transferred to the camp in Potulice; in June 1943 the camp in 
Torun also ceased to function, and also in this case the prisoners were sent to the Potulice camp (Jastrzębski, 1967, p. 107; Jastrzębski \& Jaszowski, 1968, p. 28).

Originally, the deportation action to transit camps in General Government included mainly Polish families expelled from their properties for economic reasons, as priority was to obtain housing and farms for the local Volksdeutsch population, German settlers and German administrative and party officials. The displaced Polish population had no opportunity to appeal against the occupant's decision to evict them and cease their property. Before transport to General Government, Poles were detained in transit camps, in very primitive conditions $s^{4}$, for several days or even several weeks - the period of stay depended on how long it took to form an appropriate contingent of deportees, numbering about 1000 people. After the transports to GG were stopped and the camps in Potulice, Smukała and Torun were turned into permanent reeducation labor camps, they still retained the character of displaced persons camps, which means that Polish families subject to evictions were still placed there. However, it should be noted that at that point deportations were decided not solely on the basis of economic considerations, but also political offenses committed by members of individual families, including: refusal to submit an application for entry onto the German nationals list, objection to military service in the Wehrmacht, suspected support for anti-German guerrillas, illegal return from the General Government. Of course, the accused themselves were subject to appropriate criminal procedures - only their relatives and close ones were sent to the camps (Jastrzębski, 1967, p. 44; Jastrzębski \& Jaszowski, 1968, pp. 27-28, 40-41).

The Polish population placed in transit camps went through a segregation process, which included racial and national selection and referral to work. The selection of persons qualifying - for racial and political reasons - to undergo Germanization was carried out by officers from the SS Race and Settlement Main Office (SS-Rasse- und Siedlungshauptamt), who made decisions based mainly on physical appearance of the prisoners - first dressed, then naked. External features considered as characteristic of the Nordic race were taken into account during the assessment, such as blonde hair, blue eyes, narrow nose, tall stature. Those selected for Germanization had to also be impeccable from a political point of view. Preselected persons were sent for observation to what was known as "detailed selection camps" (Feinausleselager) in Łódź. When the results of "observation" were positive, candidates for Germanization were sent to the so-called Old Reich, to

4 For more details on living conditions in transit camps see inter alia: Jastrzębski, 1967, pp. 46-61, 76-80; Jastrzębski \& Jaszowski, pp. 29, 44-92; Samselski, 2000; Ceran, 2011. 
become full-fledged members of the German nation (Jastrzębski, 1967, pp. 12, 74-75; Jastrzębski, 1968, pp. 123-131; Jastrzębski \& Jaszowski, 1968, pp. 22, 82; Ceran, 2011, pp. 68-69; Heinemann, pp. 214-220). According to the account of a former prisoner of the Potulice camp, Cecylia Samselska: "Poles, pre-selected as having biological characteristics of the German race, were sent to the camp in Łódź, where they underwent various tests, such as skull measurement, tests of hair thickness, etc. If they were found to have features of a Germanic race, they were sent with entire families deep into German territory to be subjected to Germanization" (Samselski, 2000, p. 40). In 1943, along with slowing down of the settlement action in the Reich Province Danzig-West Prussia, the number of candidates fit for Germanization due to racial and political reasons decreased in all camps managed by the Central Emigration Office due the shift in nature of their populations - made up of an increasing share of criminal prisoners. In the period from August 1, 1941 to March 15, 1943, 663 people were sent to Łódź from Potulice (Jastrzębski, 1967, p. 75). From July 31, 1941 to June 17, 1942, 607 people were sent to Łódź from the Toruń camp, usually whole families (Ceran, 2011, p. 69). It is worth mentioning that the possibility of setting up a detailed selection camp in Torun was considered, but ultimately this plan was not implemented (Sziling, 2006, p. 582). Between April 22, 1941 and the end of 1942, a total of 2504 people from the Danzig-West Prussia Province were referred to Łódź (Jastrzębski, 1968, p. 128).

Ethnic assessments were meant to identify foreign nationals fit to undergo Germanization, and local NSDAP and Security Service structures were involved in their implementation. For such selections, of key significance was the regulation of interior minister of the Reich, Wilhelm Frick, Deputy Führer Rudolf Hess and Heinrich Himmler, SS-Reichsführer, head of the German police and Reich's Commissar for the Strengthening of German Nationhood on the Ethnic German List (Volksliste) and German citizenship in the eastern territories incorporated into the Third Reich issued on March 4, 1941 (Reichsgesetzblatt 1941, I, pp. 118-120). The Polish population gathered in the transit camps was to be evaluated in terms of usefulness for the German nation and state. The so-called assessment focused mainly on ethnic origin (German ancestors), but took into account also the knowledge of German, political beliefs, mental capacity, having relatives in the Reich, reading of the surname and appearance. At the end of January 1941, the agencies responsible for the deportation action in the Reich Province of Danzig-West Prussia decided to establish several camps for people considered fit to be Germanized. The first of them, under the aegis of the Central Emigration Office, was set up in Nowe Miasto Lubawskie in May 1941, then followed the 
ones in Puck in the Wejherowo district, in Torun - in the former printing house of Edmund Stefanowicz at ul. Bażyńskich 38/44 (Goethestrasse 38/44) - and in Zamarte in the Chojnice district. With the exception of the camp in Zamarte, which operated until February 1942, all other camps were liquidated still in 1941 and on November 1, 1941, the central Germanization camp in Jabłonowo-Zamek in the Brodnica poviat (Eindeutschungslager Schloss Gosslershausen) was put in operation in their place. Its organizer and commandant was SS-Hauptsturmführer Heinz Radtke. The duration of a stay in the camp was on average from three to six months; people who had successfully passed the procedure of admission onto the German national list and the racial-ethnic assessments were sent to another transit camp in Ilsenburg in the Harz Mountains, to later be re-settled in the Reich. The Germanization camp in Jabłonowo - Zamek functioned until June 1943, with about five thousand people having passed through its gates (Jastrzębski, 1967, pp. 63-73; Jastrzębski, 1968, pp. 113-123; Jastrzębski \& Jaszowski, 1968, p. 22; Obozy hitlerowskie, pp. 200-201; Jastrzębski, 2010, pp. 107-110; Ceran, 2011, pp. 69-71).

In addition to racial and national criteria, the economic needs of the Third Reich also had to be taken into account during the settlement action - adequate supply of Polish workers had to be ensured. According to a prisoner of "Szmalcówka", Henryk Klimek, the newly arrived deported persons were greeted with the words "We, Germans, will teach you order, discipline and work" (Klimek, 2003, p. 109). Recruitment for work was at the discretion of a representative of the National Labor Office in Gdańsk (Landesarbeitsamt), who chose prisoners fit for work in German enterprises and farms in the Reich Province Danzig-West Prussia. Others were referred to work in the General Governorship or in the so-called Old Reich. Young people in good physical condition were of course preferred. In the period from April 22, 1941 to July 31, 1941, 9,367 Poles were expelled from their living quarters and farms - 946 among them were recruited by the $\mathrm{Na}$ tional Labor Office in Gdańsk (Jastrzębski \& Jaszowski, 1968, p. 26) and sent to work, mainly in German farms located in pre-war East Prussia districts: Elbląg, Kwidzyn, Malbork, Susz and Sztum (Jastrzębski, 1967, pp. 82-83). In the period from September 1, 1941 to May 31, 1942, the National Labor Office selected 1106 workers from among the prisoners of the camp in Potulice.

Prisoners also worked for the needs of the camps they were detained in. In Potulice, from the fall of 1941 till the end of summer of 1944, prisoners were engaged in construction of new camp barracks. In addition, about one hundred prisoners from the Stutthof camp were brought in - qualified craftsmen who were to help in expansion of the camp in Potulice (Jastrzębski, 1967, pp. 30-31, 46-49, 
81-82; Orski, 1999, pp. 104-106). Jan Chabiora, a prisoner of Stutthof, thus recalls his arrival in Potulice: "[...] I and about 180 of my companions were sent to Potulice as craftsmen to build the camp. We arrived in Potulice on December 4, 1941, but we were so exhausted that one of our companions died on the way, and we had to carry three others from the railway station in Nakło to Potulice because they could not walk on their own" (Jastrzębski \& Jaszowski, 1968, pp. 55-56). According to the accounts of Cecylia Badzińska and her brother Jan Lackowski: "It was decided to build another camp as a sub-camp of Stutthof. Its location was selected in the forest, by the Potulice-Nakło road. Equipment, carts, rails, shovels and similar things to expand the camp were transported in by rail. A group of SS-men and kapos, prisoner functionaries, from Stutthof arrived and started construction work. Prisoners were divided into groups by occupation. Women and children were led out onto the field, there they had to tear out the grass with roots, and bind and stack it. Men shoveled the arable soil and piled it up to the sides. Another group laid the rails, and trolleys were used to transport the collected soil to the lowlands - each cart was pulled by four people. Once a sufficient surface area was leveled up, foundations for the barracks were put up. New electric power infrastructure was built as the power plant in the monastery was too weak. A barge with 1500 bags of cement and lime landed - the entire load was transferred on the backs of prisoners within a few hours; the distance from the canal to the construction site was of about $1500 \mathrm{~m}$. Also three barges with planks arrived, and were unloaded in the same way. Children over 5 years were made to participate in the unloading process as well" (Samselski, 2000, pp. 95-96). Until October 1942, also about three hundred prisoners from the Torun Szmalcówka camp were sent to work on the extension of the camp in Potulice (Ceran, 2011, p. 76).

Prisoners were also made to work in craft workshops set up in the camps. These workshops carried out work for the camp itself, but also completed orders for outside clients. Multiple workshops functioned in the Potulice camp, among others: wheelwright and furniture workshops, ones for carpentry, saddlery and wickerwork, a shoemaker's, a tailor's, a locksmith shop and one making straw mats (Jastrzębski, 1967, pp. 49, 82; Samselski, 2000, p. 63). In November 1942 also a branch of Hansenwerke, a plane wing manufacturing plant from Piła was opened in the Potulice camp. Krystyna Nadolna worked there and remembers it thus: "I riveted metal plates in the tails and wings of the German messerschmitts that had just been put together by other prisoners. I worked in Hall no 1, with Genowefa Dobaczewska from the village of Lipienica. One of us operated a pneumatic hammer, the other one was using a bucking tool. We did it in turns [...]. This work required strength, dexterity and precision. All defects were considered 
to be sabotage and punished by perpetrators being sent to the penal company. The noise in the hall was terrible, my head and spine hurt all the time. I worked from six am to seven pm with an hour-long lunch break" (Samselski, 2000, p. 153). Fur manufacturing company Schulz from Gdańsk also had its branch in the Potulice camp. The work at Schulz furrier's shop was thus described by Cecylia Samselska: "The Schulz furrier's shop was located in the palace [...]. Women from the labor camp worked there under the supervision of Germans from the Schultz company; fur-making instructors were Jews brought in from somewhere together with their families. They lived in the palace, occupying two or three rooms. When the Germans decided that the Polish girls had learned what was needed, the Jews disappeared overnight. They were quietly transported somewhere. Because in the rooms in which they had lived they left all their personal belongings, one could suppose that they had been killed. I worked on a fur sewing machine, there were 24 such machines in the large hall on the ground floor of the palace. They were set in four rows of six. Only young women worked on these machines. Older women, including our Mother, were made to sew by hand on the first floor. The furrier company Schultz brought rabbit pelt scraps from the main plant in Gdańsk. We sewed these small pieces together into larger ones, about the width of the hand, which were then used for lining of soldiers' hats and gloves for warmth. The lining for hats and gloves was sewn in by the older women upstairs. They also repaired military uniforms, using sewing machines for that. I remember that the gloves had three fingers - separate ones for the thumb and index finger, so that the soldier could easily pull the trigger of a rifle [...]. Out work on fur sewing machines was piecewise" (Samselski, 2000, p. 71).

Prisoners were also employed in nearby workplaces and farms outside the camp. They were escorted there in the early morning hours and returned to the camp in the evening. In the camp regulations (Lagerordnung), which the commandant of the Potulice camp announced in May 1942, the issue of work was regulated in the 2nd paragraph: "Participation in labor. Assembly of workers to leave for the workplace location should be punctually at the appointed time. Only children under the age of six and those in possession of a certificate of incapacity for work issued by a camp doctor can stay in their quarters. At the sound of a bell, the work company shall begin their march to the workplace; work also ends with the ringing of a bell. Moving from one's assigned work column to another without permission is forbidden" (Samselski, 2000, pp. 57-58). The prisoners of "Szmalcówka" in Torun worked in German farms near the city of Toruń, in sawmills, carpentry workshops, plant nurseries (eg. Hentschel gardening in Górsko), they worked in forestry and in the fields, and performed construction and road works 
in the city itself. A large number of prisoners of "Szmalcówka" were employed by the Labor Office in Malbork (eg. in March 1942 the count was 570 prisoners) however, in practice they also performed work for German companies, including in Gdańsk, Gdynia and Pruszcz Gdański (Ceran, 2011, pp. 75-76). According to the memoirs of a prisoner in the Potulice camp, Maria Jankowska: "The camp authorities sent prisoners to work outside the camp. It took place on the basis of a contract between the camp and private German companies or landowners. Family members of prisoners sent to work outside remained in the camp as hostages. In the event of a prisoner's escape, they would take the family to the penal company where they lost their lives" (Samselski, 2000, p. 107). In addition, a big group of prisoners from Potulice was sent to work in the aircraft components factory in Piła where a sub-camp of the Potulice camp operated (Jastrzębski, 1967, pp. 49, 85; Jastrzębski \& Jaszowski, 1968, p. 44). It should be emphasized that the conditions in which prisoners performed work often exposed them to risk of death. Furthermore, Polish employees were subject to various types of harassment every day, including beatings and verbal abuse by their German employers.

Prisoners employed outside the camp received $25 \%$ of earnings due for their work as so-called pocket money, while the rest was seized by the camp administration. For juvenile workers, the share of so-called pocket money was even lower. At the beginning of 1943, the daily fees for the work of prisoners were fixed: they amounted to 0.90 marks per day for a woman, 1.20 for a man and 0.50 for a juvenile worker (12 years of age and up) (Jastrzębski, 1967, pp. 83-84).

The duty of work also applied to children aged 6 to 12 (Jastrzębski \& Jaszowski, 1968, p. 57). According to Henryk Klimek's account: "Children over 6 years of age also had to work. They worked the fields with various crops or beds of vegetables intended for the SS-men, were sent to do cleaning and help in construction work, collected herbs, nettles or berries in the forest - but were not allowed to consume any of the fruit of their labor. After the children worked foraging blueberries, Kapo functionaries checked their tongues for blue tint. If they were even a little blue, the child was beaten with a bullwhip, often to bleeding" (Samselski, 2000, p. 151). Older children, like adults, were involved in work on expansion of the camp, as outlined in the testimony of Cecylia Samselska: "Intensive preparations for construction of barracks on the leveled ground were ongoing. The materials needed - planks and beams - were transported by barges via the Bydgoski Canal, about a kilometer away. The prisoners were tasked with unloading these barges and carrying all the material on their back to the construction site. The older children were also made to carry these loads. My brother Edmund and I were among them. Who can count the tears of children shed on the ground of this kilometer long route as 
they carried the heavy wood (as it has not been seasoned)... We stored the boards in the alley leading from the palace to the road. There were first autumn sleets, then cold winds, then winter frost, and we were not allowed to stop working. The guards watched us to make sure we carried the prescribed number of boards on our shoulders. We had sores on our shoulders, so we helped each other by putting grass under the planks to protect them" (Samselski, 2000, p. 46).

Poles were forced to work with maximum effort - and with minimal financial outlays on the part of employers, what directly translated into living conditions. An important problem of all the camps was the lack of food. The limited or in actuality negligible food rations did not provide even basic nutrients, which meant that the prisoners were rapidly losing their strength. Kazimierz Knapik, who from the autumn of 1931 worked in the kitchen of the Potulice camp thus describes the situation in his account: "For the prisoners we prepared mostly a rutabaga soup with a small addition of potatoes. Also a soup made of nettles and overgrown lettuce was sometimes served. This is what prisoners were fed during the summer as in the winter [...] dried swedes were given instead. I know that every prisoner was supposed to consume 800 calories in meals. In my opinion, we received a lot less, because meat and fat were not added to these soups. We received $15 \mathrm{dkg}$ of bread for the whole day and some coffee. Two or three times a week, a bit of margarine or beet marmalade was served" (Jastrzębski \& Jaszowski, 1968, p. 48). In addition to malnutrition, particularly severe and serious consequences for the prisoners' health had the cold prevailing in all quarters for the displaced persons. Poles who were imprisoned in the transit camps also suffered from lack of space and even basic sanitary facilities - which favored the development of various types of infectious diseases - as well as very limited medical care. All these factors translated into high mortality rate among the prisoners. The below fragment of testimony by a female prisoner of Szmalcówka in Toruń, Marta Foksińska, gives a glimpse of the camp reality: "The conditions in the camp were very bad. We did not have beds or bunks, we slept on a cement floor, where straw was scattered lightly (a pallet). This straw was not changed and that is why there were all kinds of insects in the camp: fleas, lice, bedbugs, mice, rats [...]. People were taken to work in the city and brought back to the camp in the evening [...]. I often saw Germans beating the prisoners with clubs [...]. The toilets were built in the yard. These were just brick outhouses with toilet seats, clearly temporary, without a sewage system. People died daily in the camp. Sometimes, up to 30 bodies were transported out on one day, especially children. Most died of typhus" (Ceran, 2011, p. 138).

The role of camps managed by the Central Emigration Office evolved depending on such factors as, first and foremost, the number of inbound German settlers 
for whom housing and workplaces had to be readied, the possibility of sending the displaced Poles to the General Government territory, the course of military operations and the needs of the Third Reich. After stoppage of deportee transports to the General Government, the transit camps in Potulice, Smukała and Torun - in which initially the expelled Poles were staying only temporarily until deportation transports were formed - transformed into permanent camps where those imprisoned were used for forced labor. The duty to work was thence the supreme rule that all prisoners had to obey. The camps controlled by the Central Emigration Office became the place of acquiring cheap labor for agriculture and industrial plants in the Reich Province of Danzig-West Prussia. Also in the camps themselves workshops and branches of larger plants were created. As at January 15, 1943, 8,269 Poles were imprisoned in the Central Emigration Office camps (4,070 in Potulice, 2,550 in Torun, and 1,649 in Smukała). At the moment of liberation of the camp in Potulice, on January 20, 1945, the headcount was 11,214 prisoners (Jastrzębski, 1968, pp. 107, 108; Jastrzębski \& Jaszowski, 1968, pp. 28, 41).

Maximum exploitation of prisoners - forced laborers, in addition to obvious reasoning of an economic nature, was also intended to break human dignity, show the Poles that as "subhumans" they had no right to independent existence and could only be servants to the German "nation of masters". This approach reflected the Nazi race and ethnicity-based principles of social order. Work was not only an immanent component of the economic policy of the German occupant, but also of the Reich's demographic policy, as the living conditions in the transit camps: terror, hunger, limited medical care and hard work devastating the bodies of prisoners in fact turned these camps into places of slow dying and gradual extermination.

\section{References:}

Ceran, T. (2011). „Szmalcówka”. Historia niemieckiego obozu w Toruniu (1940-1943) na tle ideologii nazistowskiej. Bydgoszcz-Gdańsk: Instytut Pamięci Narodowej. Komisja Ścigania Zbrodni przeciwko Narodowi Polskiemu.

Datner, S., Gumkowski, J. \& Leszczyński, K. (1960). Wysiedlanie ludności z ziem polskich wcielonych do Rzeszy. Biuletyn Gtównej Komisji Badania Zbrodni Hitlerowskich $w$ Polsce, vol. XII.

Erlass des Führers und Reichskanzlers über Gliederung und Verwaltung der Ostgebiete. Vom 8. Oktober 1939. (1939). Reichsgesetzblatt, I, 2042-2043.

Erlass des Führers und Reichskanzlers zur Änderung des Erlasses über Gliederung und Verwaltung der Ostgebiete. Vom 2. November 1939. (1939). Reichsgesetzblatt, I, 2135.

Gliński, M. (1977). Stutthof obozem pracy wychowawczej od 1 X 1941 r. do 7 I 1942 r., Stutthof. Zeszyty Muzeum, 2, 212-214. 
Gräfe, M., Post, B. \& Schneider, A. (eds.). (2009). Quellen zur Geschichte Thüringens. Die Geheime Staatspolizei im NS-Gau Thüringen 1933-1945. Erfurt: Landeszentrale für politische Bildung Thüringen.

Grochowina, S. \& Kącka, K. (2014). Foundations of Nazi Cultural Policy and Institutions Responsible for Its Implementation in the Period 1933-1939. Kultura i Edukacja, 6, 173-192. DOI: 10.15804/kie.2014.06.10.

Heinemann, I. (2014). Rasa, ziemia, niemiecka krew. Gtówny Urząd Rasy i Osadnictwa SS i nowy porzadek rasowy Europy. Gdańsk: Muzeum II Wojny Światowej.

Janowicz, Z. (1951). Ustrój administracyjny ziem polskich wcielonych do Rzeszy Niemieckiej 1939-1945. Tzw. Okręgi Kraju Warty i Gdanska-Prus Zachodnich. Poznań: Instytut Zachodni.

Jastrzębski, W. \& Jaszowski, T. (1968). Potulice oskarżają. Bydgoszcz: Okręgowa Komisja Badania Zbrodni Hitlerowskich.

Jastrzębski, W. (1967). Potulice. Hitlerowski obóz przesiedleńczy i pracy (luty 1941 r.-styczeń 1945 r.). Bydgoszcz: Państwowe Wydawnictwo Naukowe.

Jastrzębski, W. (1968). Hitlerowskie wysiedlenia z ziem polskich wcielonych do Rzeszy 1939-1945. Poznań: Instytut Zachodni.

Jastrzębski, W. (2010). Hitlerowski obóz zniemczania w Jabłonowie-Zamku w latach 1941-1943 (Eindeutschungslager Schloss Gosslershausen). In: S. Grochowina, D. Kromp, J. Sziling (eds.) System obozów niemieckich na Pomorzu i terenach sasiednich (1939-1945). Toruń: Fundacja Generał Elżbiety Zawackiej.

Jastrzębski, W. \& Sziling, J. (1979). Okupacja hitlerowska na Pomorzu Gdańskim w latach 1939-1945. Gdańsk: Wydawnictwo Morskie.

Klimek, H. W. (2003). Czas utraconego dziecinstwa (1939-1945). Bydgoszcz: Świadectwo. Instytut Wydawniczy.

Madajczyk, Cz. (1970). Polityka III Rzeszy w okupowanej Polsce. vol. I. Warszawa: Państwowe Wydawnictwo Naukowe.

Obozy hitlerowskie na ziemiach polskich 1939-1945. Informator encyklopedyczny. (1979). Warszawa: Państwowe Wydawnictwo Naukowe.

Orski, M. (1999). Niewolnicza praca więźniów obozu koncentracyjnego Stutthof w latach 1939-1945. Organizacja pracy i metody eksploatacji sity roboczej. Gdańsk: Wydawnictwo Gdański.

Orski, M. (2004). Filie obozu koncentracyjnego Stutthof w latach 1939-1945. Gdańsk: Wydawnictwo Gdańskie.

Pospieszalski, K. M. (1946). Polska pod niemieckim prawem 1939-1945 (Ziemie Zachodnie). Poznań: Instytut Zachodni.

Samselski, T. (red.). (2000). Żywi i martwi o hitlerowskim obozie Potulice (1941-1945). Bydgoszcz: Instytut Wydawniczy „Świadectwo”.

Sziling, J. (2006). Germanizacja Torunia. In: M. Biskup (eds.), Historia Torunia. Vol. III, part II: W czasach Polski Odrodzonej i okupacji niemieckiej (1920-1945). Toruń: Wydawnictwo Towarzystwa Naukowego w Toruniu. 


\section{Archival sources:}

National Archives in Bydgoszcz, Central Emigration Office Camp in Potulice (1940-1945), ref. 1, Letter from Security and Security Service Inspector in Gdańsk, SS-Oberführer Helmuth Willich, of January 28, 1942, to special branches of security service in Jabłonowo, Toruń, Smukała and Potulice regarding the order of SS-Oberführer Helmuth Willich, Security Police and Security Service inspector in Gdańsk dated January 20, 1942.

National Archives in Bydgoszcz, Central Emigration Office in Gdańsk-Potulice (1939-1943), ref. 1, Order of the commandant of the Stutthof camp, Max Pauly of September 27, 1941 in the matter of taking over control of the transit camps in Potulice, Smukała and Toruń. 